\title{
Critical Review of Concept of Manovaha Srotas with Special Reference to Brain
}

\author{
Vd. Jagtap Manoj M. ${ }^{1 *}$ Vd.Jagtap Jyoti ${ }^{2}$ \\ ${ }^{1}$ Associate Professor, Rachana Sharir vibhag, YMT Ayurvedic Medical College, Kharghar. \\ ${ }^{2}$ Associate Professor, Swasthavrittavibhag, YMT Ayurvedic Medical College, Kharghar.
}

\begin{abstract}
Srotas are the channels for the purpose of secretion, conduction and transportation of body constituents. In sroto vimaniya adhyay (Cha. Vi. 5) Charakacharya has mentioned 13 srotas and their respective mulasthana except manovaha srotas. But in Charaka Sharirsthana 1/20,CharakaIndriyasthan 5/41 and Charaka Chikitsasthan9/5 manovaha srotas has been mentioned clearly. With context to Chakrapani tika on above references it is said that Hriday and Dasha Dhamani is the site of Mana. Anatomically hriday is considered as heart. But here heart cannot be considered as the site of mana. Mana does mainly functions of emotional, intellectual activities. All these are related to brain functions. In this study hriday is considered as brain not the heart. Hriday name means the organ which takes something, gives something and transports something. The brain does same activity like responses to incoming sensory, outgoing motor and nerve conduction. Hriday has also one meaning ie centre place. Brain is the part of central nervous system. Functions of brain matches with functions of mana mentioned in samhitas.
\end{abstract}

Keywords: Manovaha Srotas, Hriday, Brain,

\section{Introduction}

References of modern nervous system in Ayurvedic literature is always topic of discussion. Although all functions of Central Nervous System (CNS), Autonomous Nervous System (ANS) are mentioned as functions of Vata dosha the anatomical description of CNS, ANS is very rarely found. Yogshastra has mentioned mainly Sushumna, Ida, Pingala and many nadis. These nadis can be considered as of nervous system.

Mana which is known as mind is very well described in ayurveda. Ayurvedic scholars have mentioned role and functions of mind and body. Charakacharya has mentioned mana in sharirsthan along with functions of mana. In vimansthan he has not mentioned manovaha srotas separately but in indriyasthan and chikitsasthan manovaha srotas is mentioned. From the above references mulasthana of manovaha srotas are Hriday and Dash dhamani.

Hriday is commonly considered as Heart. Dash dhamani are considered as 10 vessels attached to heart. So heart can be considered as place of mana. But functions of mana or mind are related to central nervous system. Modern science nowdays says mind and brain are connected. Mind is a set of cognitive faculties including consciousness, perception, thinking,judgement, language and memory. So the place of mana can be Heart or something else? 
Vd. Jagtap Manoj M International Journal of Ayurvedic \& Herbal Medicine 9(2) Jan.-Feb. 2018 (3449-3451)

\section{Methods}

Literature Research was done regarding Manovaha Srotas inSamhitas. References from CharakSamhita were collected and compiled.

- सर्वशरीरस्रोतांसि गृहयन्ते, विशेषेण तु हृदयाश्रितत्वान्मनसस्तदाश्रितादश धमन्यो मनोवहा अभिधीयन्ते |

Cha. Indri. 5/41

- स्रोतांसि च मनोवहानीत्यनेन हृदयदेशसम्बन्धिधमन्यो विशेषेण मनोवहा दर्शयति;किंवा केवलमेव शरीरं म नोऽभ्यनुस्यूतं जग्राह । Cha. Chi. 9/5

This clearly indicates that hriday and dasha dhamani are mulasthana of manovaha srotas. The various nirukti are found for word Hriday. One means the centre of something. Hruharati, da dadati, yayati means the place where something is given, something is taken and it transports.

Analysis was made regarding the exact site of mana as described in manovaha srotas. Brain and Heart both were considered as hriday. Functions of brain, heart and fuctions of mana as well mind were compared and accordingly conclusion was drawn.

\section{Discussion}

Mana in Sanskrit means to think, believe, imagine \& suppose. It is Nitya and Anu.

\section{चिन्त्यं विचार्यमूहयं च ध्येयं सङ्कल्प्यमेव च| यत्किर्चिन्मनसो ज्ञेयं तत् सर्वं हयर्थसश्जकम्||}

These are the functions of mana. Chintya means thinking, Vicharya means analysis, Uhya means speculation, Dhyeya means aim/goal. Sankalpa means decision.

The brain is responsible for cognition which functions through numerous processes and executive functions. Executive functions include ability to filter information and tune out irrelevant stimuli with attention control and cognitive inhibition, the ability to process and manipulate information held working memory, the ability to think about multiple concepts simultaneously and switch tasks with cognitive flexibility and ability to determine the relevance of information or appropriateness of an action.

In this study brain was considered as hriday as mulasthana of manovaha srotasin relation to the following points.

$>$ According the Sanskrit literature meaning of hriday is centre place; brain is also centre place of nervous system.

$>$ Nirukti of Hriday is Hruharati, Da dadati, Yayati meaning a place where something is taken, something is given and place of exchange. Brain gives the commands (motor function) receives information (sensory function). Hence it fits the etymology of hriday.

$>$ If we observe base of skull then 10 openings are seen from which 12 cranial nerves and spinal cord exit. If we consider brain as hriday then these 10 exits of skull with cranial nerves can be correlated with Dasha Dhamani.

$>$ So for manovaha srotas we can say that the word hriday means brain not heart.

$>$ As per Charakacharya functions of Mana are

$$
\begin{aligned}
& \text { इन्द्रियाभिग्रहः कर्म मनसः स्वस्य निग्रहः| } \\
& \text { ऊहो विचारश्च, ततः परं बुद्धिः प्रवर्तते||२१॥ Cha. Sha.1/21 }
\end{aligned}
$$

Control of sense organs, self-restraint, hypothesis and consideration represent the action of the mind. Beyond that flourishes the domain and intellect.

$>$ Heart does not have any cognitive, intellectual or psychological function. 
Vd. Jagtap Manoj M International Journal of Ayurvedic \& Herbal Medicine 9(2) Jan.-Feb. 2018 (3449-3451)

$>$ Whereas brain performs many functions including cognitive, psychological functions. So brain is seat of Mind.

\section{Conclusion}

as per discussion we can conclude that brain can be considered as hriday and dasha dhamani can considered as cranial nerves. Charakacharya must have seen 10 exits at abse of skull and cranial nerves are coming out of it hence it has been described as Dasha Dhamani. Since brain is inside skull and its centre point of nervous system it is mentioned as hriday.

\section{References}

1. Shastri S. CharakSamhita. Vol. 1. Varanasi , Uttar Pradesh: Chaukhambha Bhararti Academy ; 2002.Sharirsthan 1

2. Shastri S. CharakSamhita. Vol. 1. Varanasi, Uttar Pradesh: Chaukhambha Bhararti Academy ; 2002. Indriyasthan 5

3. Shastri S. CharakSamhita. Vol. 1. Varanasi , Uttar Pradesh: Chaukhambha Bhararti Academy ; 2002. Chiktsasthan 9

4. Cranial Nerves [Internet]. wikipedia.org. [cited 2019Jan27]. Available from: https://en.wikipedia.org/wiki/Cranial_nerves

5. Vilensky, Joel; Robertson, Wendy; Suarez-Quian, Carlos (2015). The Clinical Anatomy of the Cranial Nerves: The Nerves of "On Olympus Towering Top". Ames, Iowa: WileyBlackwell. ISBN 978-1-118-49201-7.

6. Drake, Richard L.; Vogl, Wayne; Tibbitts, Adam W.M. Mitchell; illustrations by Richard; Richardson, Paul (2005). Gray's anatomy for students. Philadelphia: Elsevier/Churchill Livingstone. pp. 800-807. ISBN 978-0-8089-2306-0. 